\title{
Effect of Ethanol Content on Thermal Efficiency of a Spark-Ignition Light-Duty Engine
}

\author{
Luigi De Simio, Michele Gambino, and Sabato Iannaccone \\ Istituto Motori, Italian National Research Council, Via Marconi 8, 80125 Naples, Italy \\ Correspondence should be addressed to Luigi De Simio, 1.desimio@im.cnr.it
}

Received 20 April 2012; Accepted 9 August 2012

Academic Editors: M. S. Abdel-Mottaleb and S. Karellas

Copyright () 2012 Luigi De Simio et al. This is an open access article distributed under the Creative Commons Attribution License, which permits unrestricted use, distribution, and reproduction in any medium, provided the original work is properly cited.

The use of bioethanol in the transport sector can contribute to mitigate the greenhouse gas emissions of the vehicles. To achieve this goal, together with a positive energy balance in global productive process of ethanol (well to tank), it is important that adding ethanol to gasoline does not cause a worsening of the efficiency of the internal combustion engine (tank to wheel). In this paper, a research activity on a commercial spark-ignition light-duty engine at the test bench is reported. The aim of the work was to characterize the effect of different bioethanol/gasoline blends on engine behaviour. Blends until 85\% of ethanol were tested. Comparative studies of combustion development of gasoline and gasoline/ethanol blends at different concentrations have been made through the analysis of pressure cycles in combustion chamber. Moreover, emissions were collected and analyzed. Emissions downstream of the catalyst, measured with the blends, resulted quite similarly to the gasoline case. Instead, upstream the catalyst a reduction of emissions, proportional to oxygenated content was noted. Moreover, a general carbon dioxide reduction with ethanol blends was achieved due in particular to better engine thermal efficiency.

\section{Introduction}

The increasing costs and climate change related to fossil fuels exploitation require a major share of the energy production from alternative sources, in particular from waste or renewable sources. Recently, great attention is given to the use of biomass to produce fuels, especially for transport as alternative to petrol. Biofuels production becomes extremely interesting when obtained from waste or residual of other human activities, but in this case, the limited feedstock could contribute only with a small impact on the reduction of the fossil fuel demand. The use of bioethanol in the transport sector can contribute to mitigate the greenhouse gas emissions of the vehicles. The benefits are strictly connected with the efficiency of ethanol global productive process, taking into account also land use competition with other human needs.

The octane number of pure ethanol is higher than gasoline; therefore, it is an optimal fuel to improve performance of Otto engines since the risk of knock decreases [1]. Ethanol can be used pure or mixed with gasoline. Anyway, the use of pure ethanol implies some problems during cold start due to vaporization lower than gasoline, which in some cases should require an electrical preheating of the engine block [2]. Also the problem of corrosion implies that the fuel system must be made using stainless steel and rubber, compatible. More resistant materials should be used (e.g., for the valve seats) due to ethanol lower lubricants properties. Finally, the lower heating value (LHV) of ethanol requires an alteration of the injection control to increase the fuel flow. Therefore, only a limited percentage of ethanol can be used in conventional gasoline engine. However, the diffusion of flexible fuel vehicles (FFVs), designed to operate with any gasolineethanol mixtures, [3-5], is increasing. The advantage of FFV systems consists in the possibility offered by the control system of the engine to detect the concentration of ethanol in the tank and automatically optimize both injection and ignition.

The influence of alcohol/gasoline blends on spark ignition internal combustion engine performance and emissions was largely investigated. Bibliographic data highlight a general reduction of engine-out emission [6-8]. Also a positive effect of alcohol content on thermal efficiency was noted, both on a single-cylinder engine at the test bed [9] 
TABLE 1: Engine main characteristics.

\begin{tabular}{lc}
\hline & Naturally aspirated 4-cylinder in-line, stoichiometric spark ignition \\
\hline Bore $\times$ stroke & $80.5 \mathrm{~mm} \times 78.4 \mathrm{~mm}$ \\
Total displacement & $1596 \mathrm{~cm}^{3}$ \\
Volumetric compression ratio & $10.5: 1$ \\
Rated power & $76 \mathrm{~kW}$ at $5750 \mathrm{rpm}$ \\
Rated torque & $144 \mathrm{Nm}$ at $4000 \mathrm{rpm}$ \\
Number of valves per cylinder & $4(2$ for intake-2 for exhaust $)$ \\
NG feeding system & Electronic timed multipoint \\
\hline
\end{tabular}

and on a vehicle on a chassis dynamometer [10, 11]. Blending ethanol with gasoline was also found to permit a higher compression ratio without knock occurrence [12]. A review of ethanol/gasoline blends impact on internal combustion engines is given in [13].

In this paper, gasolines E10, E20, E30, and E85 (resp. $10 \%, 20 \%, 30 \%$, and $85 \% \mathrm{v} / \mathrm{v}$ of ethanol in gasoline) were tested on commercial light duty engine for passengers car at the test bench to valuate in particular the effect of ethanol content on thermal efficiency at parity of in-cylinder cycle pressure.

\section{Research Activities}

2.1. Experimental Apparatus. The planned objective of the experimental activity was the characterization of engine behaviour with different gasoline/ethanol blends in terms of emissions and performance, mainly efficiency and combustion development. The engine used in the tests was a 1.6-litre spark ignition engine equipped with a three-way catalyst (TWC) at the exhaust, whose main characteristics are reported in Table 1. A picture of the engine connected at test bench is shown in Figure 1.

For optimization of engine parameters and electronic control unit (ECU) data storage, the Magneti Marelli Helios board with dedicated software has been used. Before starting experimental activity, engine head has been substituted in order to install a pressure transducer in the combustion chamber of cylinder no. 3 and some thermocouples to monitor the head temperature in significant points, such as the seat between intake and exhaust valve, the zone close to the spark plug. In Figure 2, a picture of the instrumented engine head is reported.

Gaseous emissions have been measured with a hot Beckman 404 flame ionization detector (FID) for THC, a hot ABB UV Limas 11 for nitrogen oxides $\left(\mathrm{NO}_{x}\right)$, and a cold $\mathrm{ABB}$ URAS 14 for $\mathrm{CO}, \mathrm{CO}_{2}$, and oxygen. A Coriolis mass flow meter was used for the fuel consumption.

The tests have been performed with pure gasoline and increasing the ethanol content by volumes of 10,20,30, and $85 \%$.

In Table 2, main characteristics of gasoline, pure ethanol and tested blends are shown.

The lower heating value (LHV) of gasoline reported in Table 2 is a mean value from the technical literature. For

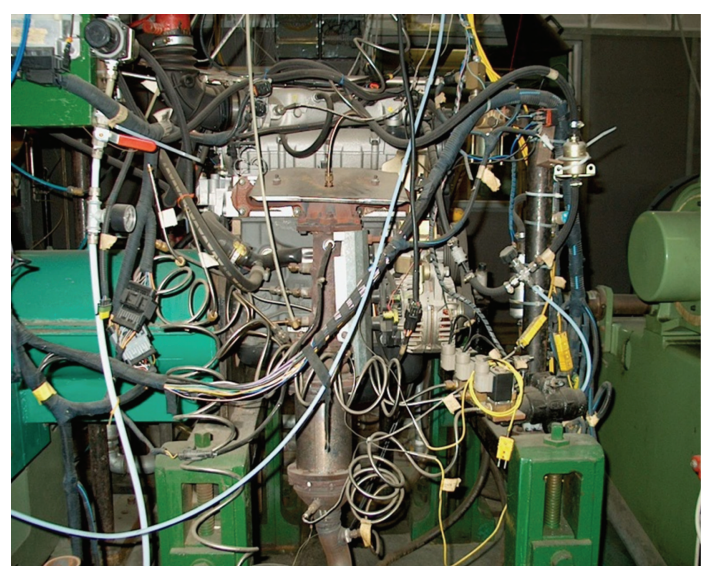

FIGURE 1: Spark ignition engine at the test bed.

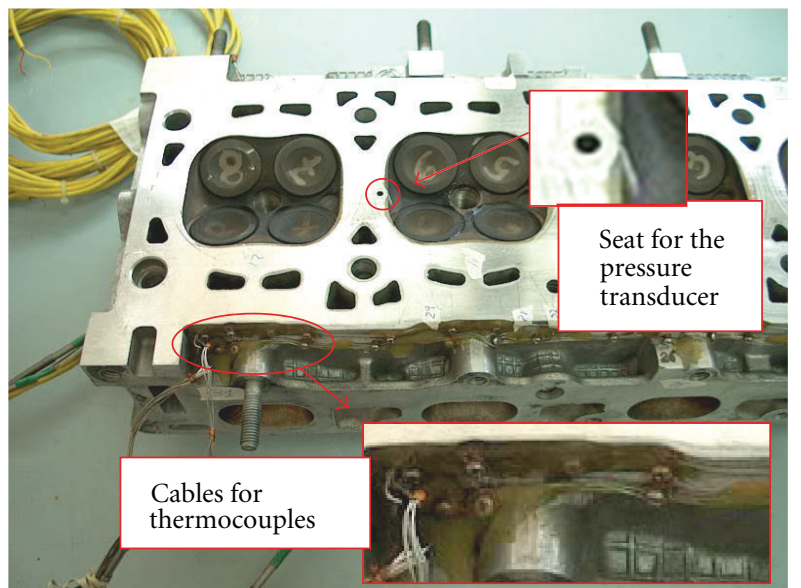

FIGURE 2: Engine head equipped with the seat for the pressure transducer and some thermocouples.

calculation of engine efficiency, a variation in the range $41 \div 44 \mathrm{MJ} / \mathrm{kg}$ has been considered. Instead, for pure ethanol, the LHV is well defined. At ethanol content increasing, the LHV decreases, and therefore, a higher fuel flow rate, with respect to gasoline, is necessary at parity of engine load and efficiency. Instead, at ethanol content increasing in gasoline, the air mass required to burn the same mass of fuel in stoichiometric conditions decreases. The heat content of 
TABLE 2: Gasoline, ethanol, and tested blends main characteristics.

\begin{tabular}{|c|c|c|c|c|c|c|c|c|c|c|}
\hline & $\begin{array}{c}\mathrm{A} / \mathrm{F} \\
\mathrm{kg} / \mathrm{kg}\end{array}$ & $\begin{array}{l}\mathrm{LHV} \\
\mathrm{MJ} / \mathrm{kg}\end{array}$ & $\begin{array}{c}\rho \\
\mathrm{kg} / \mathrm{m}^{3}\end{array}$ & $\begin{array}{l}\text { Ethanol } \\
\% \text { mass }\end{array}$ & $\begin{array}{c}\mathrm{C} \\
\% \text { mass }\end{array}$ & $\begin{array}{c}\mathrm{H} \\
\% \text { mass }\end{array}$ & $\begin{array}{c}\mathrm{O} \\
\% \text { mass }\end{array}$ & $\begin{array}{c}\mathrm{gCO}_{2} / \mathrm{MJ} \\
\mathrm{g} / \mathrm{MJ}\end{array}$ & $\begin{array}{l}H_{\text {st,mix }}{ }^{a} \\
\mathrm{MJ} / \mathrm{kg}\end{array}$ & $\begin{array}{c}H_{v}{ }^{\mathrm{b}} \\
\mathrm{kJ} / \mathrm{kg}\end{array}$ \\
\hline Gasoline & 14.32 & 42.5 & 750 & 0 & 85 & 13 & 1 & 73.4 & 2.77 & 400 \\
\hline E10 & 13.77 & 40.9 & 754 & 10 & 82 & 13 & 5 & 73.3 & 2.77 & - \\
\hline E20 & 13.22 & 39.3 & 757 & 20 & 78 & 13 & 8 & 73.1 & 2.76 & - \\
\hline E30 & 12.68 & 37.7 & 761 & 30 & 75 & 13 & 12 & 72.9 & 2.75 & - \\
\hline E85 & 9.77 & 29.2 & 780 & 85 & 57 & 13 & 30 & 71.5 & 2.71 & - \\
\hline Ethanol & 9.01 & 26.9 & 785 & 100 & 52 & 13 & 35 & 71.0 & 2.69 & 850 \\
\hline
\end{tabular}

${ }^{a}$ Heat content of stoichiometric mixture.

${ }^{\mathrm{b}}$ Latent heat of vaporization.

TABLE 3: Test conditions with gasoline and ethanol/gasoline blends.

\begin{tabular}{lccc}
\hline $\begin{array}{l}\text { Speed } \\
\text { rpm }\end{array}$ & \multicolumn{2}{c}{$\begin{array}{c}\text { Torque/BMEP } \\
\text { Nm/bar }\end{array}$} \\
\hline 1750 & $20 / 1.9$ & $50 / 4.1$ & $80 / 6.6$ \\
2050 & $20 / 1.9$ & $50 / 4.1$ & $80 / 6.6$ \\
3000 & $20 / 1.9$ & $50 / 4.1$ & $80 / 6.6$ \\
\hline
\end{tabular}

stoichiometric mixture takes into account both the LHV and the stoichiometric air fuel ratio. The fact that this value is similar for all the tested blends implies that the total mass flow rate (air + fuel) is only slightly reduced, at parity of engine load and efficiency and at ethanol content increasing. Therefore the same mass has to be aspirated by the engine. Anyway, a higher heat of vaporization of ethanol can reduce the mixture temperature, increasing the density and reducing the volume of the mixture to be aspirated. Grams of $\mathrm{CO}_{2}$ per MJ of fuel consumed are only slightly reduced by ethanol. Therefore, a tank-to-wheel $\mathrm{CO}_{2}$ reduction can be obtained with ethanol blends, only if engine efficiency improves.

The tests have been carried out on a grid of nine speed/load conditions, ranging from 1750 to $3000 \mathrm{rpm}$ and from 20 to $80 \mathrm{Nm}$ (Table 3). These points have been selected within the area of the new European driving cycle (NEDC) test; therefore, they are representative of the most common operating conditions.

\section{Test Results}

The engine was tested in closed-loop stoichiometric condition, assured by ECU. Instead, spark advance (SA) has been optimized, with a calibration tool software (HELIOS), to have the peak pressure at $13 \div 16$ crank angle degree $(\mathrm{CAD})$ after top dead centre, for all the tested blends. SA was changed with respect to that set by the standard ECU for two reasons.

(1) The standard ECU follows as SA strategy to reduce emissions on the NEDC cycle, and therefore, in some conditions, it achieves a combustion delayed with respect to the optimal angle to reduce $\mathrm{NO}_{x}$ emissions.

(2) Furthermore, the ECU showed a trend to reduce $\mathrm{SA}$ at ethanol content increasing. At steady-state condition, the ECU sets the SA principally on the base

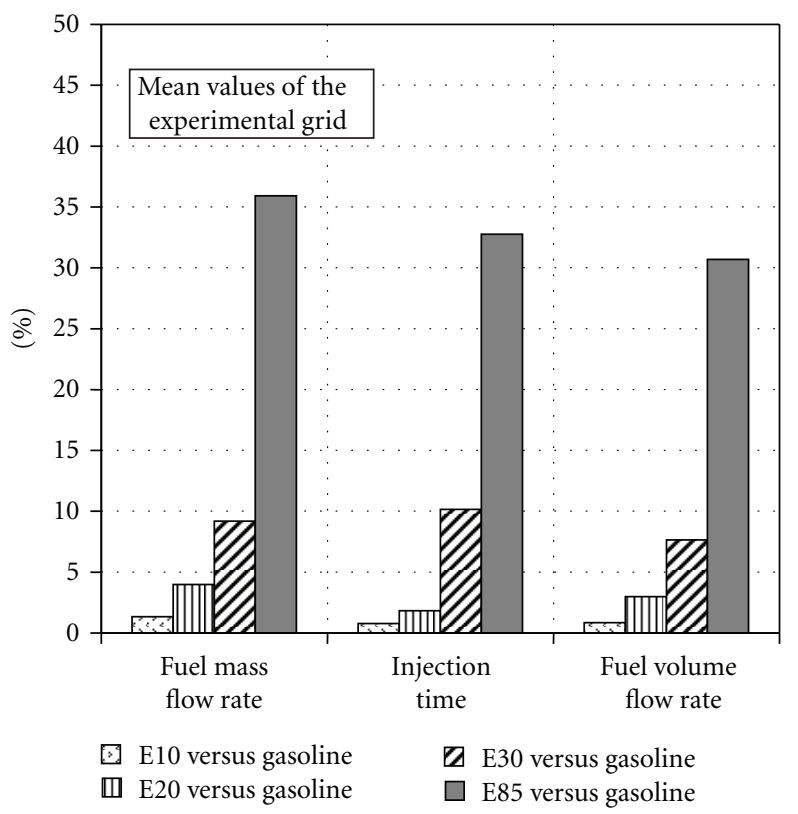

FIgURE 3: Fuel mass flow rate, injection time, and fuel volume flow rate as mean values of the experimental points.

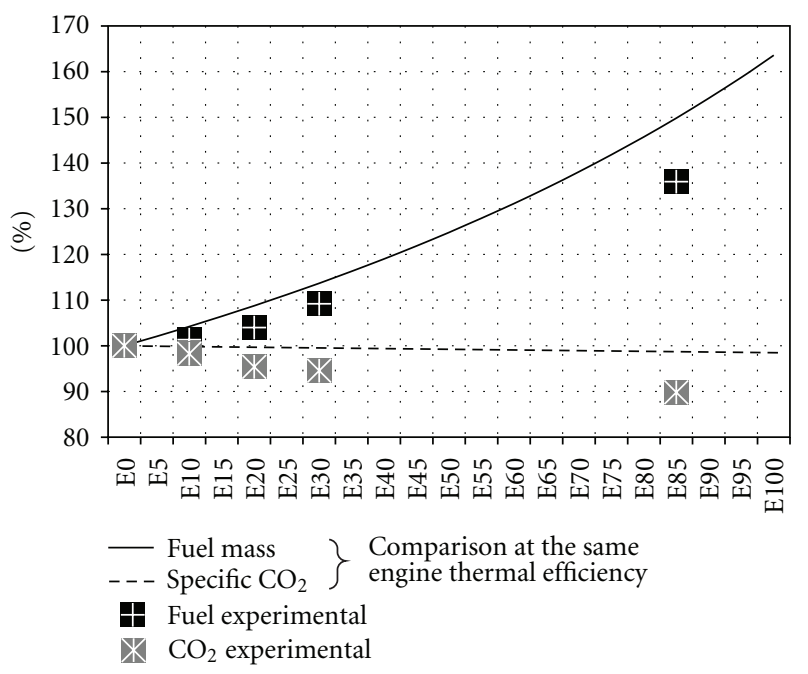

FIGURE 4: Theoretical and experimental values of fuel consumption and $\mathrm{CO}_{2}$ emissions. 
TABLE 4: Spark advance, manifold absolute pressure, and throttle position for all the tested fuels.

\begin{tabular}{|c|c|c|c|c|c|c|c|c|c|c|c|c|c|c|c|}
\hline & \multicolumn{3}{|c|}{ Gasoline } & \multicolumn{3}{|c|}{ E10 } & \multicolumn{3}{|c|}{ E20 } & \multicolumn{3}{|c|}{ E30 } & \multicolumn{3}{|c|}{ E85 } \\
\hline & $\begin{array}{c}\mathrm{SA} \\
{[\mathrm{CAD}]}\end{array}$ & $\begin{array}{c}\text { MAP } \\
{[\mathrm{mbar}]}\end{array}$ & $\begin{array}{c}\mathrm{TP} \\
\circ\end{array}$ & $\begin{array}{c}\mathrm{SA} \\
{[\mathrm{CAD}]}\end{array}$ & $\begin{array}{c}\text { MAP } \\
{[\text { mbar }]}\end{array}$ & $\begin{array}{c}\mathrm{TP} \\
\circ\end{array}$ & $\begin{array}{c}\mathrm{SA} \\
{[\mathrm{CAD}]}\end{array}$ & $\begin{array}{c}\text { MAP } \\
{[\mathrm{mbar}]}\end{array}$ & $\begin{array}{c}\text { T.P. } \\
\circ\end{array}$ & $\begin{array}{c}\mathrm{SA} \\
{[\mathrm{CAD}]}\end{array}$ & $\begin{array}{c}\text { MAP } \\
{[\mathrm{mbar}]}\end{array}$ & $\begin{array}{c}\text { T.P. } \\
\circ\end{array}$ & $\begin{array}{c}\mathrm{SA} \\
{[\mathrm{CAD}]}\end{array}$ & $\begin{array}{c}\text { MAP } \\
{[\mathrm{mbar}]}\end{array}$ & $\begin{array}{c}\text { T.P. } \\
\circ\end{array}$ \\
\hline 1750 and 20 & 37.6 & 414 & 7 & 37.8 & 412 & 7 & 37.2 & 405 & 7 & 36.9 & 393 & 7 & 35.1 & 422 & 6 \\
\hline 1750 and 50 & 30.5 & 605 & 11 & 31.1 & 595 & 11 & 30.6 & 592 & 11 & 30.5 & 585 & 11 & 29.5 & 607 & 10 \\
\hline 1750 and 80 & 27.7 & 791 & 15 & 27.8 & 783 & 15 & 27.6 & 776 & 15 & 27.4 & 782 & 16 & 25.8 & 791 & 15 \\
\hline 2050 and 20 & 41.5 & 384 & 8 & 44.2 & 375 & 7 & 41.8 & 381 & 8 & 42.2 & 375 & 9 & 40.5 & 386 & 7 \\
\hline 2050 and 50 & 31.1 & 565 & 12 & 35.0 & 571 & 12 & 34.1 & 568 & 12 & 34.4 & 558 & 13 & 33.0 & 569 & 11 \\
\hline 2050 and 80 & 29.6 & 751 & 16 & 32.1 & 738 & 16 & 31.5 & 740 & 16 & 31.9 & 733 & 17 & 29.9 & 748 & 16 \\
\hline 3000 and 20 & 41.7 & 405 & 9 & 41.8 & 404 & 9 & 41.7 & 408 & 9 & 41.5 & 419 & 11 & 37.8 & 405 & 8 \\
\hline 3000 and 50 & 34.3 & 578 & 15 & 34.4 & 575 & 14 & 35.6 & 559 & 14 & 34.1 & 595 & 16 & 33.5 & 570 & 14 \\
\hline 3000 and 80 & 29.0 & 756 & 20 & 32.1 & 751 & 19 & 32.0 & 748 & 20 & 31.6 & 775 & 21 & 29.1 & 754 & 19 \\
\hline Mean value & 33.7 & 583 & 12 & 35.1 & 578 & 12 & 34.7 & 575 & 12 & 34.5 & 579 & 13 & 32.7 & 584 & 12 \\
\hline
\end{tabular}

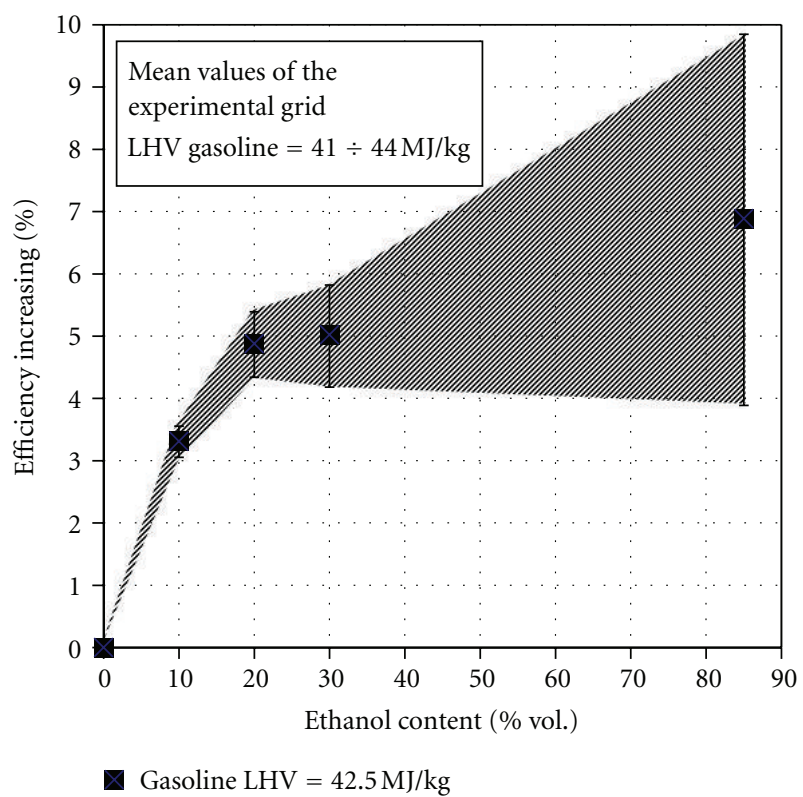

FIGURE 5: Engine efficiency as mean value of the nine experimental points.

of engine coolant temperature, speed, and manifold absolute pressure (MAP). With all the tested blends at each speed and load condition no difference on MAP was found, since the heat content of stoichiometric air/fuel mixture is almost not influenced by the content of ethanol in the blend, and therefore, the engine must intake the same total mass (air + fuel). At the same engine speed and MAP, the ECU should set the same SA. Instead, the lower SA that ECU sets at ethanol content increasing could be due to the selfadaptive algorithms implemented in the ECU and influenced by the comparison between the mapped value of the injection time to a given load and the value set to have a stoichiometric mixture. In fact, the increase of the ethanol content, in closed-loop

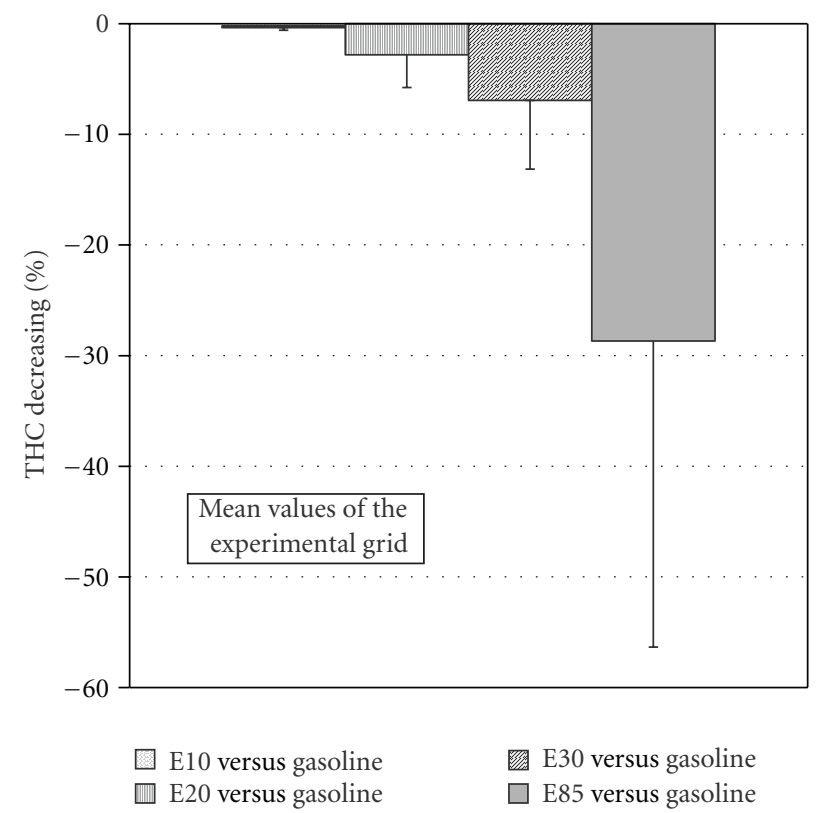

Figure 6: Engine-out THC emission as mean value of the nine experimental points.

condition, leads to larger injection times to maintain the stoichiometric mixture at a given load.

In Table 4, SA, MAP, and throttle position (TP) in each experimental point and for all the tested fuels are shown. The optimal spark advance with each blend resulted to be more or less the same as the gasoline case. Injection times are reported in Figure 3 as mean values of the experimental grid. Injection time, fuel mass, and volume flow rate increase with alcohol content in the blends, in agreement with the reduction of LHV of the blends.

Anyway, the observed fuel mass increasing with ethanol content is appreciably lower than that predictable on the base of tested fuel characteristics. In Figure 4, experimental fuel mass flow rate (as mean value of the experimental grid) resulted to be lower than the theoretical values, calculated 


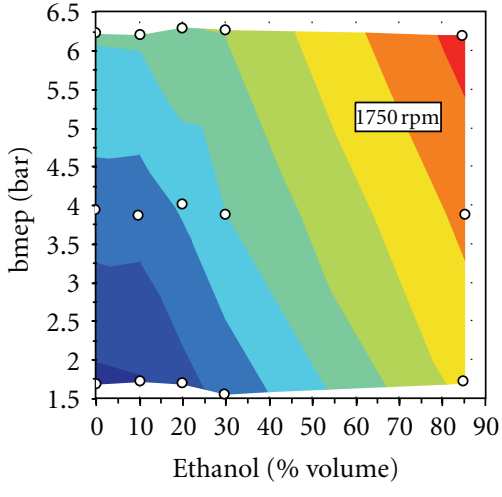

- Experimental points

(a)

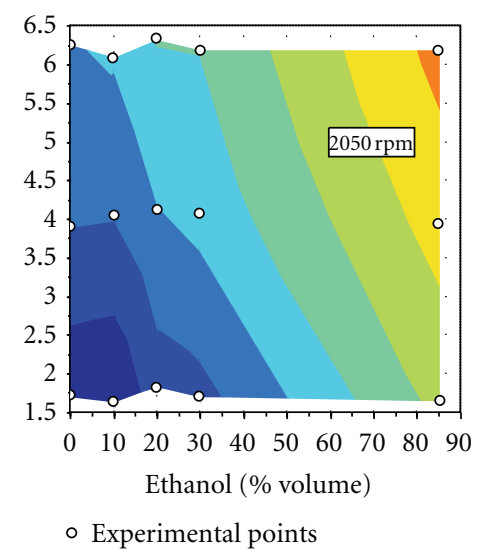

(b)

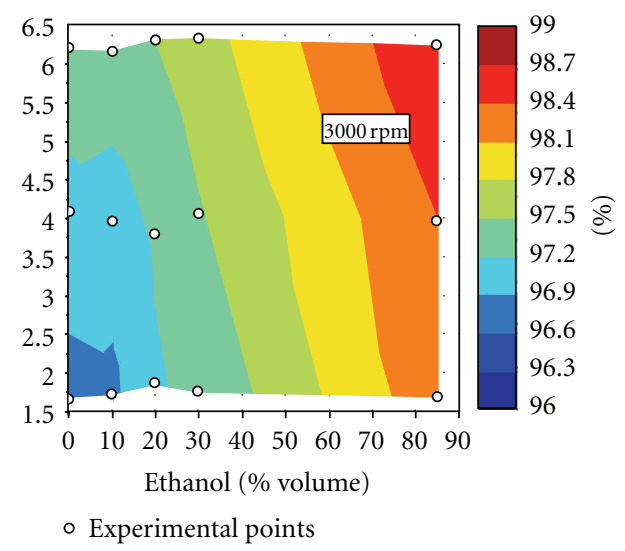

(c)

Figure 7: Combustion efficiency at different engine speeds as a function of ethanol content in blends.

from LHV of Table 2. To confirm these results, the nine experimental points have been repeated for a large time to compare fuel consumption given by the Coriolis mass flow rate with the measures of a precision electronic balance (with a accuracy of $0.1 \mathrm{~g}$ ). The two measuring systems provided the same results. In the figure, also $\mathrm{CO}_{2}$ emission is reported.

In Figure 5, effect of ethanol content on engine efficiency increasing with respect to gasoline is reported. In the figure,

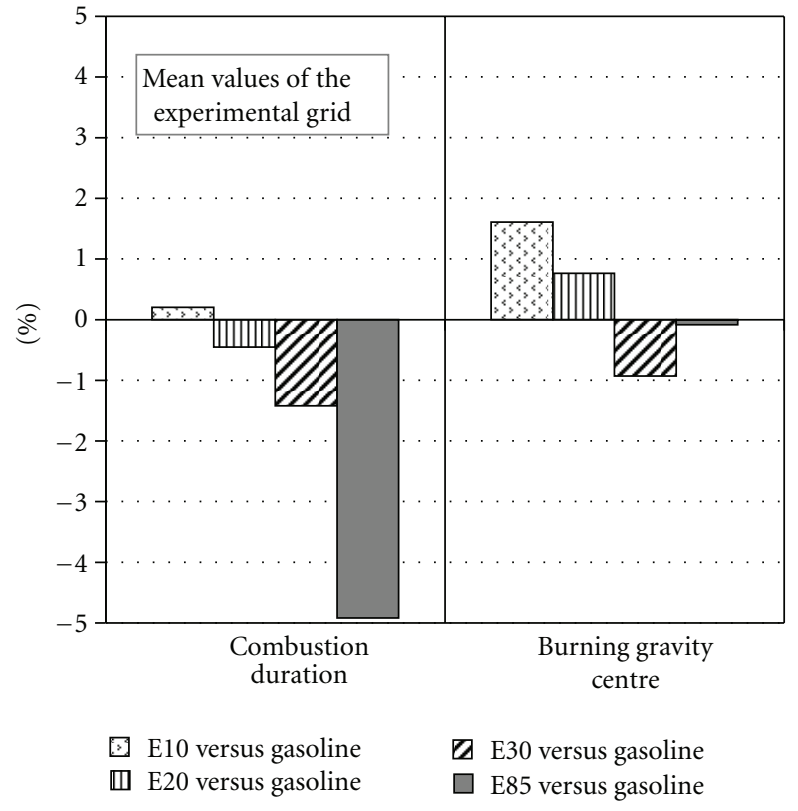

FIGURE 8: Combustion duration at parity of BGC as mean value of the experimental grid.

the highlighted area was obtained considering the LHV of gasoline ranging from 41 to $44 \mathrm{MJ} / \mathrm{kg}$. With the addition of ethanol was obtained an increase of efficiency greater than $3 \%$. The 4 to $10 \%$ efficiency improving obtained with E85 is the most uncertain value as it is strongly influenced by the performance of the gasoline case, since E85 has a more different composition from gasoline than any other ethanol blend.

The improved efficiency obtained with the addition of ethanol may be justified by several causes. First of all, the higher oxygen content of the fuel gives a better combustion. In Figure 6, emission of unburned hydrocarbon measured at the exhaust before the TWC is reported as an average value of the experimental grid. The error bars are relative to the value as measured by the FID analyzer, while the correct values were obtained by applying corrective factors to the measured concentrations, as suggested in [14], to take into account the lower FID sensitivity towards oxygenated compounds. Also, CO emission, not reported, showed a similar trend, before the TWC. From fuel consumption, THC and CO emissions combustion efficiency was evaluated. An improvement was achieved with increasing the content of ethanol in all speed conditions tested, as shown in Figure 7.

Also, the combustion speed was improved with ethanol, even if of slight amount. The combustion duration, valuated as the time between the SA and the $90 \%$ fuel mass burned, was reduced (Figure 8) at parity of burning gravity centre (BGC). Therefore, the same cycle pressure development was obtained (Figure 9) but with a slightly lower SA.

As reported in Table 4, no difference in TP and MAP was observed; therefore, no reduction of pumping loss was achieved. In Figure 10, the pumping cycles at $50 \mathrm{Nm}$ (bmep 


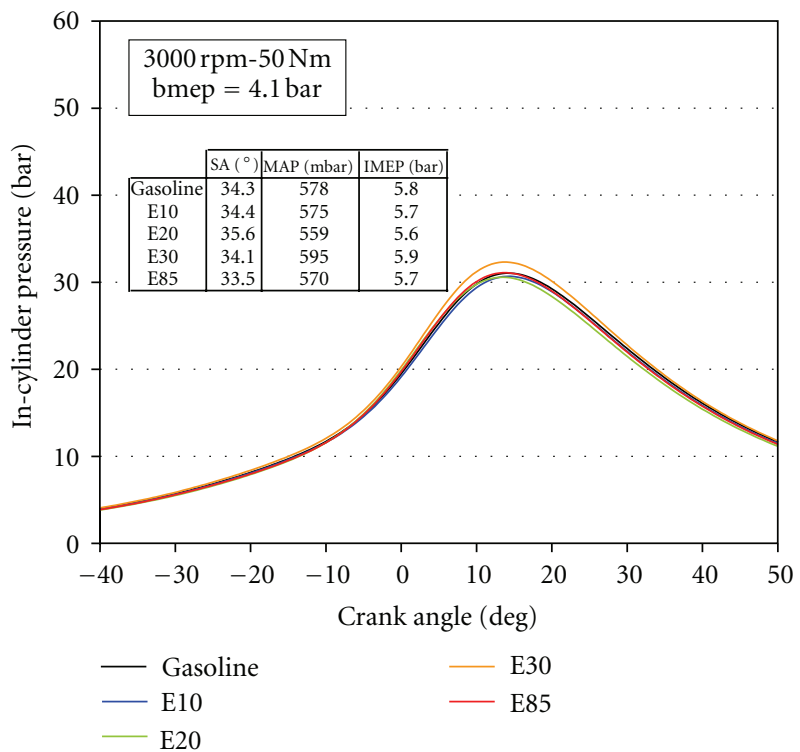

(a)

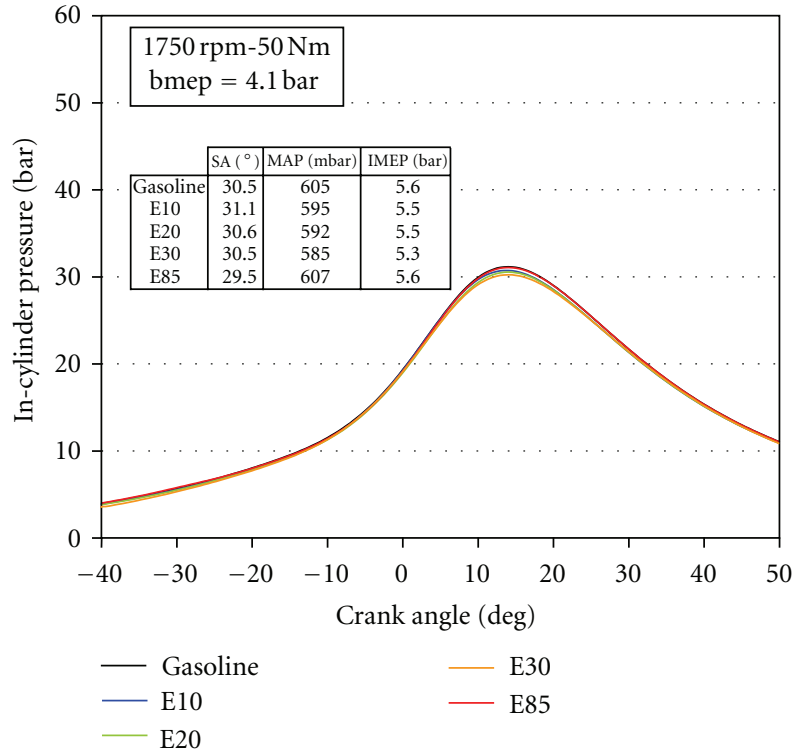

(b)

Figure 9: In-cylinder pressure at 4.1 bmep load at 3000 and $1750 \mathrm{rpm}$ for the tested blends.

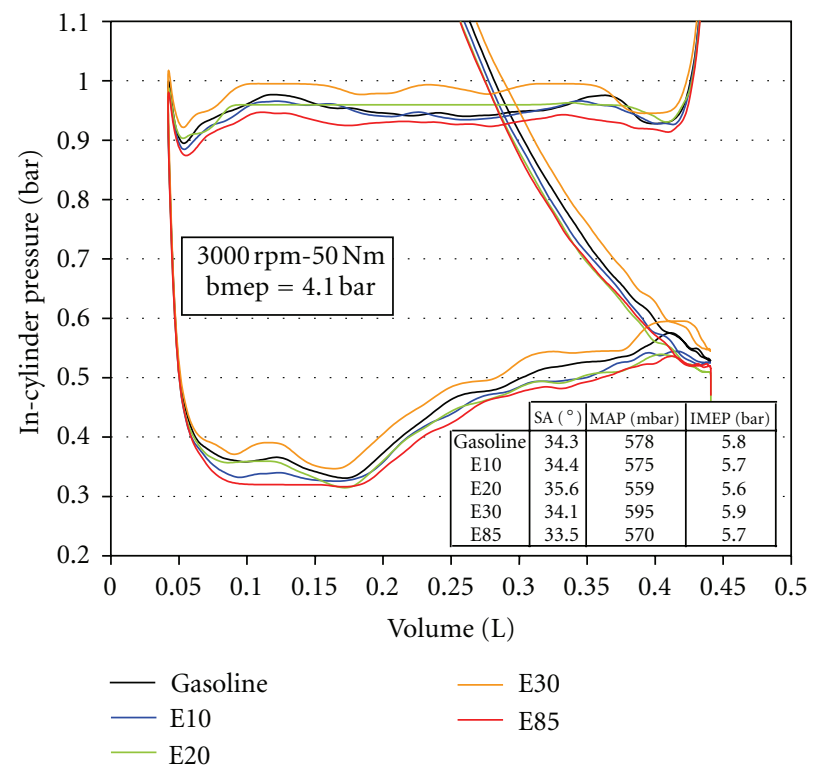

(a)

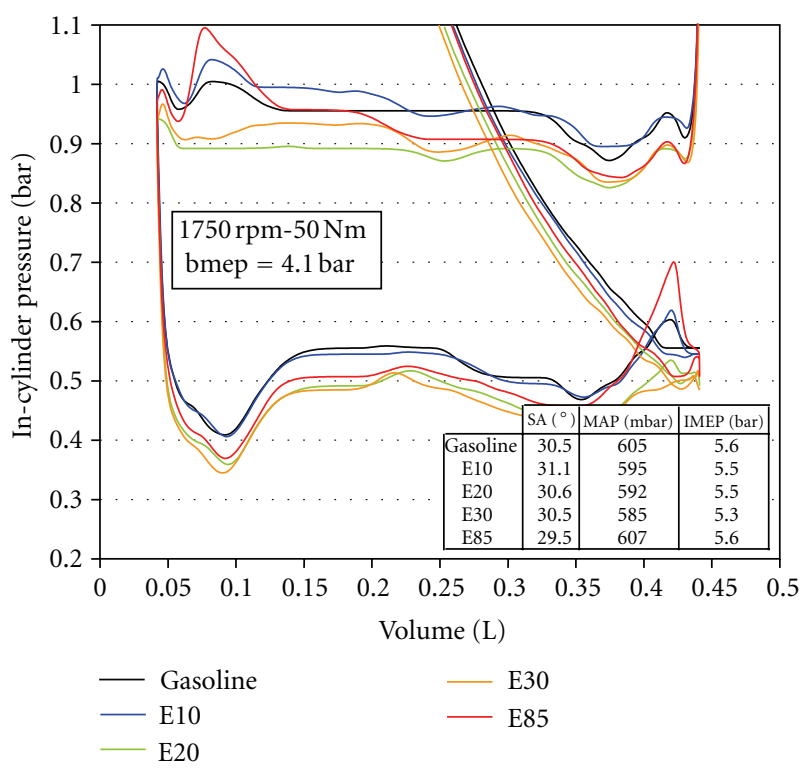

(b)

FIGURE 10: In-cylinder pumping cycle at 4.1 bmep at 3000 and $1750 \mathrm{rpm}$ for all the tested blends.

4.1 bar) and $1750 \mathrm{rpm}$ and $3000 \mathrm{rpm}$ are plotted for all the tested fuels.

Instead, some further benefits on efficiency could be deriven from a lower temperature intake mixture. Ethanol increases the heat of vaporization of the air fuel mixture that evaporates during compression. This makes the compression stroke more close to the isothermal one, which results in lower compression work. Some researchers tried to obtain this effect with water injection $[15,16]$. This effect is hard to view with experimental data and should be of small entity. Anyway, data acquired from the head thermocouples reported in Figures 11 and 12 can be used to do some considerations.

The intake mixtures temperatures (Figure 11) are not affected by the ethanol content. This temperature was measured after the section of the injector and before the intake duct of each cylinder is divided into two ducts which lead to the two intake valves. The fuel injected within the fluid mass is not yet evaporated in this section, and therefore, the temperature of the mixture is not affected. The 


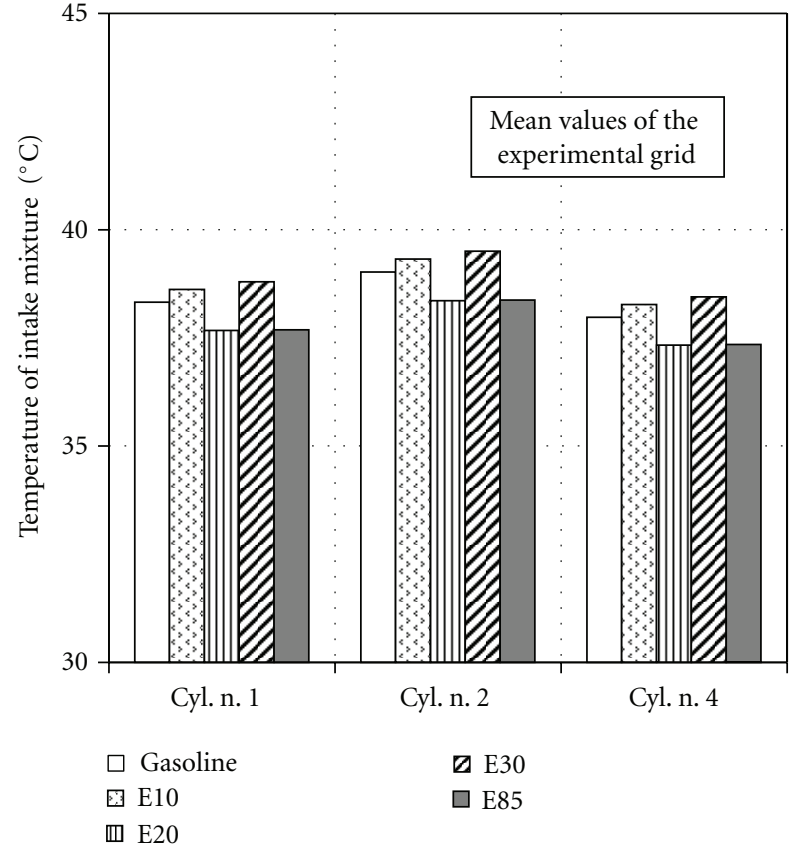

FIGURE 11: Intake mixture temperatures for all the tested blends as mean values of the experimental grid.

fuel evaporates principally during the compression stroke when temperature increases. Instead, the temperature of the material in the seat between the two intake valves seems to be influenced by the ethanol content in the fuel. In fact, it has a decreasing trend with ethanol content increase for all the monitored cylinders. The wall temperature at the intake port was measured in the seat between the intake valves. This temperature can be influenced by the fuel impingement on the walls that evaporates. The increase of the latent heat of evaporation of the fuel, given by a higher content of ethanol, could justify the trend of the measured temperature. No differences were found on the exhausts port where there is no fuel impingement.

The effect of ethanol on reducing the temperature of the mixture could also be derived from the $\mathrm{NO}_{x}$ emissions upstream the TWC. As shown in Figure 13, $\mathrm{NO}_{x}$ are reduced, at ethanol content increasing, probably due to the lower peak temperature in the combustion chamber, due to a cooling effect of the charge prior to the combustion.

\section{Conclusions}

A traditional port injection spark-ignited engine was found to be not significantly influenced by the content of ethanol in gasoline. The engine was fuelled with blends until 85\% by volume of ethanol. The standard ECU was able to control air/fuel composition retaining the target stoichiometric value with regular operation. Instead, spark advance set by the original ECU is affected by the ethanol content at parity of engine load, probably due to the injection time increasing that affects the logic controller. In the experimental activity, SA has been modified using a calibration tool software to

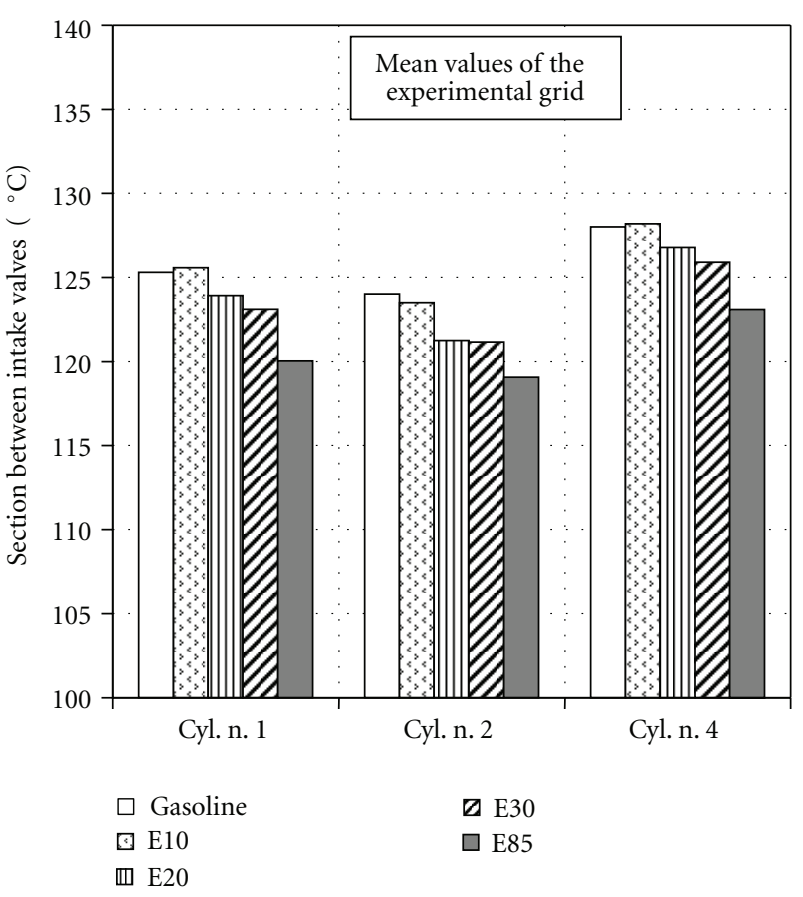

(a)

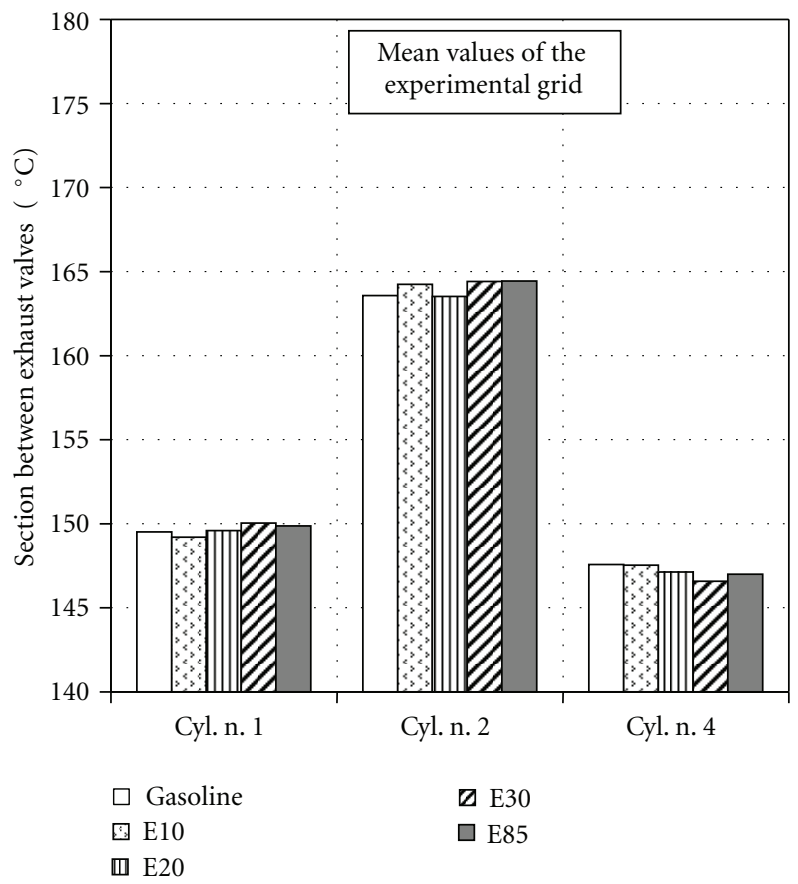

(b)

Figure 12: Engine head temperatures for all the tested blends as mean values of the experimental grid.

compare the engine behaviour with all the tested blends at parity of in-cylinder cycle development.

A positive trend between the ethanol content and efficiency of the engine was found. In the paper, the efficiency improvement was analyzed with the available experimental data and considering a range of variability of gasoline lower 


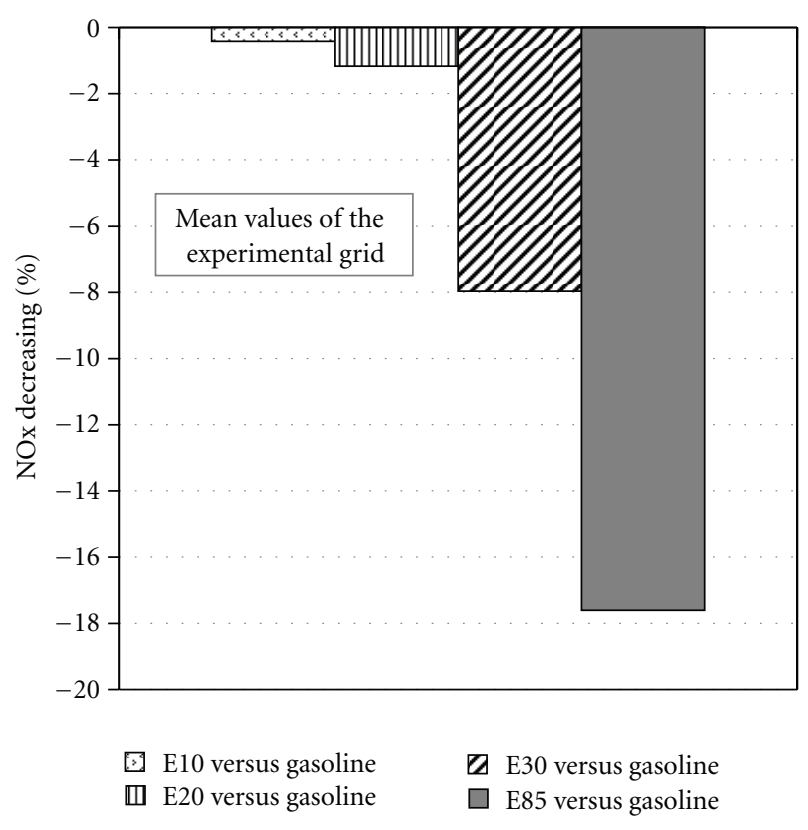

FIgURE 13: Engine-out $\mathrm{NO}_{x}$ emission as mean value of the nine experimental points.

heating value of $41 \div 44 \mathrm{MJ} / \mathrm{kg}$. A minimum benefit of $3 \div 4 \%$ of engine efficiency improving was obtained. Therefore, a reduction of tank-to-wheel $\mathrm{CO}_{2}$ emission can be achieved using gasoline/ethanol blends if the engine control unit is able to set the correct spark advance. The same spark advance of the gasoline case could be used to achieve the found efficiency improvement and to reduce emissions upstream the three-way catalyst.

\section{References}

[1] J. K. Paul, Ethyl Alcohol Production and Use as a Motor Fuel, Noyes Data Corporation, Park Ridge, NJ, USA, 1979.

[2] L. C. M. Sales and J. R. Sodré, "Cold start emissions of an ethanol-fuelled engine with heated intake air and fuel," Fuel, vol. 95, pp. 122-125, 2012.

[3] T. C. Cordeiro de Melo, G. B. Machado, C. R. P. Belchior et al., "Hydrous ethanol-gasoline blends-combustion and emission investigations on a flex-fuel engine," Fuel, vol. 97, pp. 796-804, 2012.

[4] R. C. O. B. Delgado, A. S. Araujo, and V. J. Fernandes, "Properties of Brazilian gasoline mixed with hydrated ethanol for flex-fuel technology," Fuel Processing Technology, vol. 88, no. 4, pp. 365-368, 2007.

[5] C. Bastian-Pinto, L. Brandão, and M. de Lemos Alves, "Valuing the switching flexibility of the ethanol-gas flex fuel car," Annals of Operations Research, vol. 176, no. 1, pp. 333-348, 2010.

[6] B. Q. He, J. X. Wang, J. M. Hao, X. G. Yan, and J. H. Xiao, "A study on emission characteristics of an EFI engine with ethanol blended gasoline fuels," Atmospheric Environment, vol. 37, no. 7, pp. 949-957, 2003.

[7] M. Al-Hasan, "Effect of ethanol-unleaded gasoline blends on engine performance and exhaust emission," Energy Conversion and Management, vol. 44, no. 9, pp. 1547-1561, 2003.
[8] J. R. Tavares, M. S. Sthel, L. S. Campos et al., "Evaluation of pollutant gases emitted by ethanol and gasoline powered vehicles," Procedia Environmental Sciences, vol. 4, pp. 51-60, 2011.

[9] I. Schifter, L. Diaz, R. Rodriguez, J. P. Gómez, and U. Gonzalez, "Combustion and emissions behavior for ethanol-gasoline blends in a single cylinder engine," Fuel, vol. 90, no. 12, pp. 3586-3592, 2011.

[10] M. Eyidogan, A. N. Ozsezen, M. Canakci, and A. Turkcan, "Impact of alcohol-gasoline fuel blends on the performance and combustion characteristics of an SI engine," Fuel, vol. 89, no. 10, pp. 2713-2720, 2010.

[11] A. Irimescu, "Fuel conversion efficiency of a port injection engine fueled with gasoline-isobutanol blends," Energy, vol. 36, no. 5, pp. 3030-3035, 2011.

[12] T. Topgül, H. S. Yücesu, C. Çinar, and A. Koca, "The effects of ethanol-unleaded gasoline blends and ignition timing on engine performance and exhaust emissions," Renewable Energy, vol. 31, no. 15, pp. 2534-2542, 2006.

[13] R. K. Niven, "Ethanol in gasoline: environmental impacts and sustainability review article," Renewable and Sustainable Energy Reviews, vol. 9, no. 6, pp. 535-555, 2005.

[14] S.-D. Charlotte, METEV, Measurement Technology for Emissions from Ethanol Fuelled Vehicles AVL MTC, 9711, AVL MTC AB, 2009/11, 2009.

[15] H. Özcan and M. S. Söylemez, "Thermal balance of a LPG fuelled, four stroke SI engine with water addition," Energy Conversion and Management, vol. 47, no. 5, pp. 570-581, 2006.

[16] V. Subramanian, J. M. Mallikarjuna, and A. Ramesh, "Effect of water injection and spark timing on the nitric oxide emission and combustion parameters of a hydrogen fuelled spark ignition engine," International Journal of Hydrogen Energy, vol. 32, no. 9, pp. 1159-1173, 2007. 

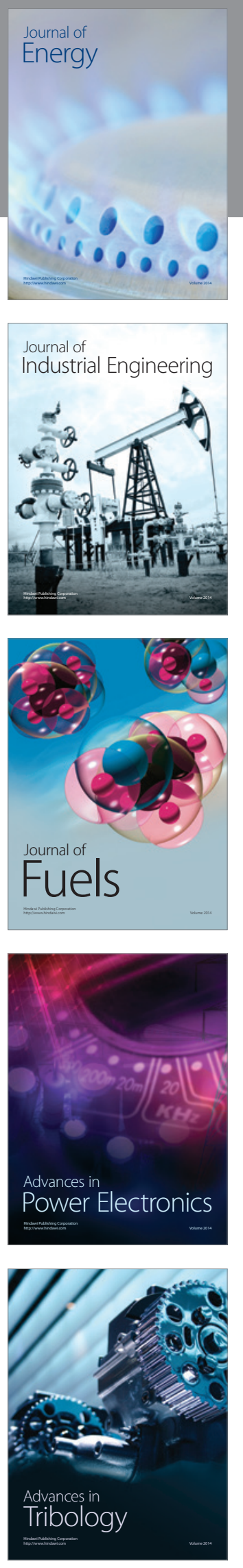
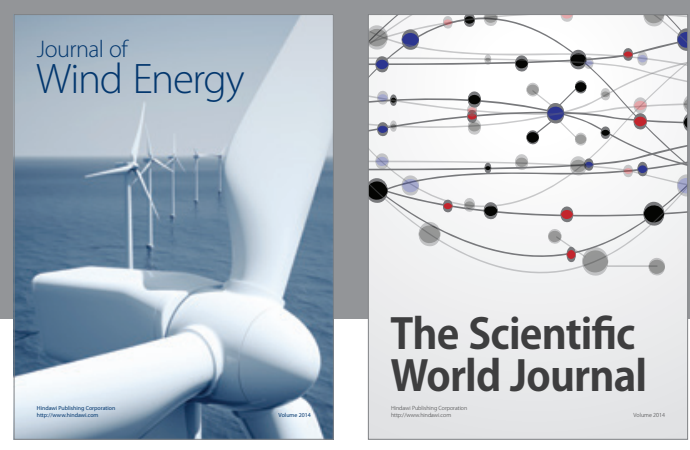

The Scientific World Journal

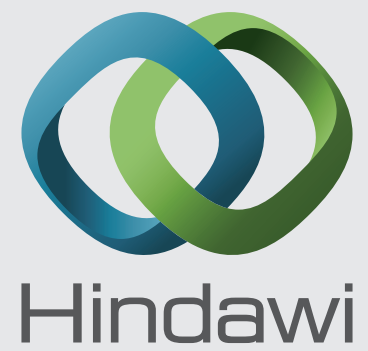

Submit your manuscripts at http://www.hindawi.com
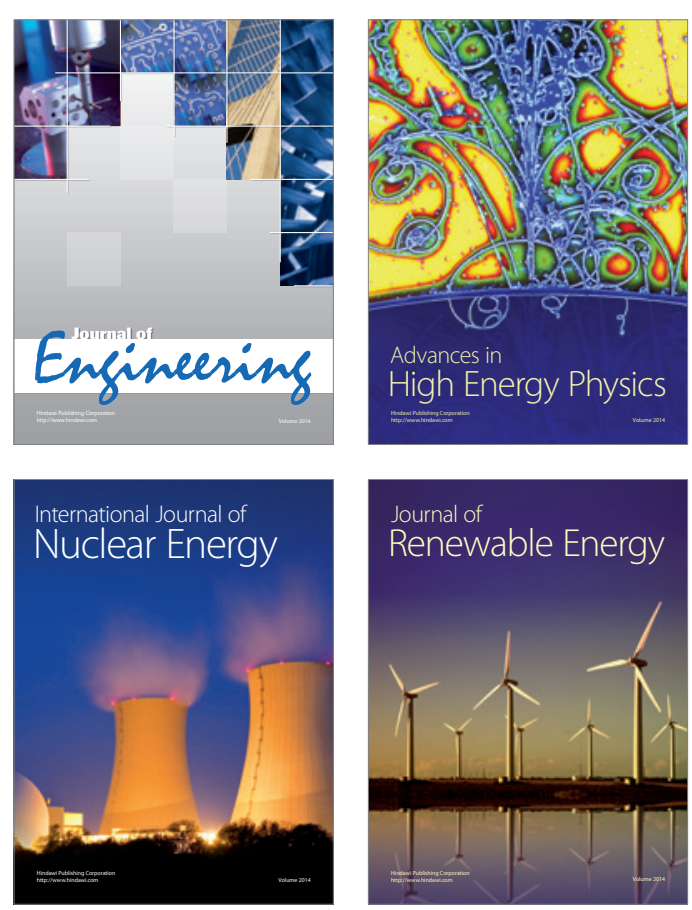

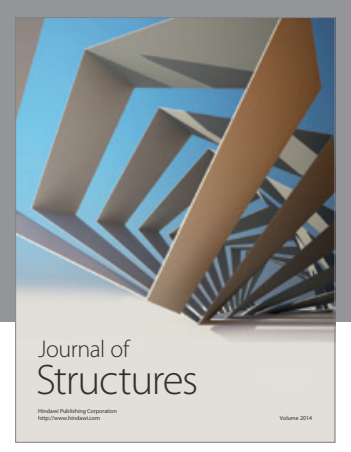

Rotating
Mechinery
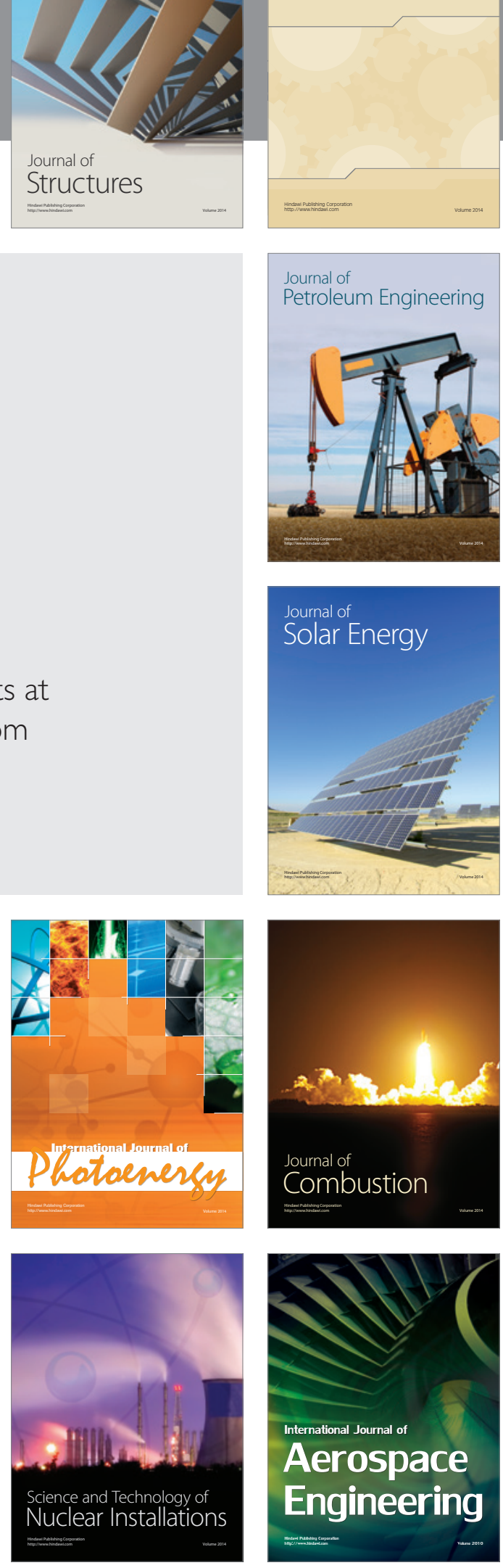